New Trends and Developments in Vaccines 


\title{
New Trends and Developments in Vaccines
}

\author{
Edited by \\ A. Voller \\ Nuffield Laboratories of Comparative Medicine, Institute of Zoology, \\ Zoological Society of London; and \\ H. Friedman \\ Department of Microbiology, Albert Einstein Medical Center, \\ New York
}


This book is based in part on an international symposium organized by ROBERT S. FIRST, INC. which is located at 405 Lexington Avenue, New York, N.Y. 10017 and Avenue Marnix 19A, 1050 Brussels, Belgium. ROBERT S. FIRST, INC. specializes in Market and Economic Research, Conferences, and Publications in all phases of the Health Care Industry.

Published by

MTP Press Limited

St Leonard's House

St Leonardgate

Lancaster, England

Copyright (C) 1978 MTP Press Limited

Softcover reprint of the hardcover 1st edition 1978

All rights reserved. No part of this publication may be reproduced, stored in a retrieval system, or transmitted in any form or by any means, electronic, mechanical, photocopying, recording or otherwise, without prior permission from the publishers.

ISBN-13: 978-94-011-6632-4 e-ISBN-13: 978-94-011-6630-0 DOI: $10.1007 / 978-94-011-6630-0$

Trowbridge \& Esher 


\section{Contents}

List of Contributors vii

Preface $\quad$ ix

1. Introduction

H. Friedman and A. Voller 1

2. New developments in vaccines

$\begin{array}{ll}\text { W. Hennesen } & 7\end{array}$

3. Paediatric vaccines

$\begin{array}{lr}\text { S. A. Plotkin } & 19\end{array}$

4. The whooping cough vaccine controversy

G. Dick

5. Measles vaccines

E. Norrby

6. Vaccines against influenza

C. Hannoun

7. The New York Swine Influenza Immunization Program

P. J. Imperato

8. Rabies vaccines

J. Crick

9. Rubella vaccines

C. Huygelen

10. Vaccination against poliomyelitis

J. Salk and D. Salk

11. Hepatitis viruses and vaccines

M. R. Hilleman, V. M. Villarejos, E. B. Buynak, O. L.

Ittensohn, W. J. McAleer, Arlene A. McLean, W. J. Miller, P. J. Provost, A. A. Tytell and B. S. Wolanski

12. Developments with hepatitis B vaccines

A. J. Zuckerman 


\section{CONTENTS}

13. Herpesvirus vaccine development: studies of virus morphological components

S. K. Vernon, W. C. Lawrence, Carole A. Long, G. H. Cohen and B. A. Rubin

14. Ribosomal vaccines: a review

T. K. Eisenstein

15. Cholera vaccines

H. Friedman

16. A vaccine for the prevention of pneumococcal infections

G. Schiffman

17. Meningococcal vaccines

W. A. Hankins

18. Development of meningococcal vaccines

R. Triau

19. Immunization with streptococcus mutans against dental caries in Rhesus monkeys

T. Lehner, S. J. Challacombe and Jill Caldwell

20. Vaccination against tropical parasitic diseases

A. Voller

21. Notes on veterinary vaccines

A. J. Beale

22. Standardization and control of allergen extracts

W. D. Brighton 


\section{List of Contributors}

\section{J. BEALE}

Head, Biological Department, Wellcome Research Laboratories, Beckenham, Kent BR3 3BS

\section{W. D. BRIGHTON}

Head, Laboratory of Allergens, National Institute for Biological Standards and Control, Hampstead, London NW3 6RB

\section{E. B. BUYNAK}

Division of Virus and Cell Biology Research, Merck Institute for Therapeutic Research, West Point, Pennsylvania 19486, USA

\section{JILL CALDWELL}

Department of Oral Immunology and Microbiology, Guy's Hospital Medical and Dental Schools, London SEI 9RT

\section{S. J. CHALLACOMBE}

Department of Oral Immunology and Microbiology, Guy's Hospital Medical and Dental Schools, London SE1 9RT

\section{G. H. COHEN}

Wyeth Laboratories Inc.,

Philadelphia, Pennsylvania 19101, USA

\section{J. CRICK}

Biochemistry Department, Animal Virus Research Institute, Woking, Surrey GU24 ONF

\section{G. DICK}

Regional Postgraduate Dean, University of London Postgraduate Medical Foundation, London NWI 5HD

\section{T. K. EISENSTEIN}

Department of Microbiology and Immunology, Temple University School of Health, Health Services Center, Philadelphia, Pennsylvania 19140, USA

\section{H. FRIEDMAN}

Head, Department of Microbiology, Albert Einstein Medical Center, Philadelphia, Pennsylvania 19140, USA

\section{W. A. HANKINS}

Manager, Research and Development, Connaught Laboratories Inc., Swiftwater, Pennsylvania 18370, USA

\section{HANNOUN}

Viral Ecology Unit, Institut Pasteur, F-75724 Paris, France

\section{W. HENNESSEN \\ Behringwerke, \\ D-3550 Marburg/Lahn, West Germany}

\section{R. HILLEMAN}

Director, Division of Virus and Cell Biology Research, Merck Institute for Therapeutic Research, West Point, Pennsylvania 19486, USA

\section{HUYGELEN}

Director of Research,

Recherche et Industrie Therapeutique SA, B-1330 Rixensart, Belgium

\section{P. J. IMPERATO}

First Deputy Commissioner, New York City Department of Health, New York, New York 10013, USA 


\section{VACCINES: TRENDS AND DEVELOPMENTS}

\section{O. L. ITTENSOHN}

Division of Virus and Cell Biology

Research, Merck Institute for Therapeutic

Research, West Point, Pennsylvania

19486, USA

\section{W. C. LAWRENCE}

Wyeth Laboratories Inc.,

Philadelphia, Pennsylvania 19101, USA

\section{T. LEHNER}

Department of Oral Immunology and

Microbiology, Guy's Hospital Medical

and Dental Schools, London SEI 9RT

\section{CAROLE A. LONG}

Wyeth Laboratories Inc.,

Philadelphia, Pennsylvania 19101, USA

\section{W. J. McALEER}

Division of Virus and Cell Biology

Research, Merck Institute for Therapeutic

Research, West Point, Pennsylvania 19486, USA

\section{A. A. McLEAN}

Division of Virus and Cell Biology

Research, Merck Institute for Therapeutic

Research, West Point, Pennsylvania 19486, USA

\section{W. J. MILLER}

Division of Virus and Celi Biology

Research, Merck Institute for Therapeutic

Research, West Point, Pennsylvania 19486, USA

\section{E. NORRBY}

Professor and Head, Department of Virology, Karolinska Institutet, S-105-21 Stockholm, Sweden

\section{S. A. PLOTKIN}

Director of Infectious Diseases, Virus Laboratory, Joseph Stokes Jr. Research Institute, Children's Hospital, Philadelphia, Pennsylvania 19101, USA

\section{P. J. PROVOST}

Division of Virus and Cell Biology Research, Merck Institute for Therapeutic Research, West Point, Pennsylvania 19486, USA

\section{B. A. RUBIN}

Manager, Biological Products Department, Wyeth Laboratories Inc.,

Philadelphia, Pennsylvania 19101, USA

\section{SALK}

Departments of Pathology and Biochemistry, University of Washington, Seattle, Washington, USA

\section{J. SALK}

The Salk Institute, PO Box 1809,

San Diego, California 92112, USA

\section{G. SCHIFFMAN}

Wyeth Laboratories Inc., Philadelphia, Pennsylvania 19101, USA

\section{R. TRIAU}

Medical Director, Institut Merieux, F-19002 Lyon, France

\section{A. A. TYTELL}

Division of Virus and Cell Biology Research, Merck Institute for Therapeutic Research, West Point, Pennsylvania 19486, USA

\section{S. K. VERNON}

Wyeth Laboratories Inc.,

Philadelphia, Pennsylvania 19101, USA

\section{M. VILLAREJOS}

Louisiana State University International Center for Medical Research and Training, San Jose, Costa Rica

\section{A. VOLLER}

Nuffield Laboratories of Comparative Medicine, Institute of Zoology, The Zoological Society of London. Regent's Park, London NW1 4RY

\section{B. S. WOLANSKI}

Division of Virus and Cell Biology Research, Merck Institute for Therapeutic Research, West Point, Pennsylvania 19486, USA

\section{A. J. ZUCKERMAN}

Professor and Head, Department of Microbiology, and WHO Collaborating Centre for Reference and Research on Viral Hepatitis, London School of Hygiene and Tropical Medicine, London WC1E 7HT 


\section{Preface}

It was not too long ago that many physicians and biomedical scientists felt that the era of 'vaccines' for protecting mankind against infectious disease was coming to an end. During the 1940s and 50s the widespread use of newly developed antibiotics and antimicrobial chemotherapeutic agents suggested a new era in medicine, i.e. the control and eventual elimination of all infectious diseases, at least those caused by bacteria, by chemical means. The magic 'bullet' proposed by Paul Ehrlich in the early 1900s seemed to be the method of choice for controling infection. However, it is now quite evident that those high expectations were unwarranted. Although many acute infections, especially those caused by pyogenic cocci, have been controlled by antibiotics, it is quite evident that infectious diseases, even those caused by bacteria, still are a major problem. Thus, the old 'standby' of preventative vaccination is making a strong comeback, not only for viral but also for bacterial infections. However, except for a relatively small number of viral diseases and those bacterial diseases due to toxin elaborated by microorganisms rather than invasion and replication of the microbe per se, preventative vaccination still has not fulfilled the expectations of their proponents.

There has been a recent resurgence of interest concerning all aspects of vaccines, not only their preparation and administration, but also the nature and mechanism of the host immune response to the constituent microorganisms and their products. A number of recent symposia, conferences, and scientific sessions at national and international meetings have been devoted to the subject of vaccines. This volume is an outgrowth of an international meeting held in Brussels, Belgium under the sponsorship of the Robert S. First Co. At the Conference a number of presentations were made in attempts to answer some of the vital questions concerning the value of various vaccines for bacterial, viral, parasitic and fungal infections, as well as newer developments in this ares. Both fundamental and clinical aspects of vaccine development, use, and applications were discussed. A number of participants were then asked to contribute chapters to this volume. In addition other investigators actively participating in either development or use of newer vaccines for a variety of purposes were also asked to contribute to this volume. No attempt was made to cover completely every aspect of vaccines, either 


\section{VACCINES: TRENDS AND DEVELOPMENTS}

historical or prospectives for the future. It is anticipated that further conferences as well as publications dealing with this rapidly re-emerging area of microbial immunology and preventative medicine will, within the next few years, permit the realization of many hopes by biomedical scientists that infectious diseases can be controlled by appropriate immunological 'engineering,' i.e. administration of effective and safe vaccines.

The editors are grateful to contributors to this volume who obviously gave of their time and effort in preparing manuscripts. The editors are also grateful to the staff of MTP Press for their forebearance and assistance. We also wish to acknowledge the excellent assistant of Ms. Leony Mills, Albert Einstein Medical Center, Philadelphia, Penna. for various editorial aspects in preparing this volume.

Herman Friedman

Alister Voller

January 1978 